\title{
The importance of mouse models to define immunovirologic determinants of progressive multifocal leukoencephalopathy
}

\author{
Elizabeth L. Frost ${ }^{1}$ and Aron E. Lukacher ${ }^{2}$ * \\ 1 Immunology and Molecular Pathogenesis Graduate Program, Emory University, Atlanta, GA, USA \\ ${ }^{2}$ Department of Microbiology and Immunology, The Pennsylvania State University College of Medicine, Hershey, PA, USA
}

\section{Edited by:}

Yassine Taoufik, Université Paris-Sud, France

\section{Reviewed by:}

Nancy Monson, University of Texas Southwestern Medical Center, USA Nicholas Schwab, University of

Muenster, Germany

\section{*Correspondence:}

Aron E. Lukacher, Department of Microbiology and Immunology, H107, The Pennsylvania State University College of Medicine, 500 University Drive, Hershey, PA 17033, USA e-mail: alukacher@hmc.psu.edu
Progressive multifocal leukoencephalopathy $(P M L)$ is a severely debilitating and often fatal demyelinating disease of the central nervous system (CNS) in immunosuppressed individuals caused by JC polyomavirus (JCV), a ubiquitous human pathogen. Demyelination results from lytically infected oligodendrocytes, whose clearance is impaired in the setting of depressed JCV-specific T cell-mediated CNS surveillance. Although mutations in the viral capsid and genomic rearrangements in the viral non-coding region appear to set the stage for PML in the immunosuppressed population, mechanisms of demyelination and CNS antiviral immunity are poorly understood in large part due to absence of a tractable animal model that mimics PML neuropathology in humans. Early studies using mouse polyomavirus (MPyV) in T cell-deficient mice demonstrated productive viral replication in the CNS and demyelination; however, these findings were confounded by spinal cord compression by virus-induced vertebral bone tumors. Here, we review current literature regarding animal models of $\mathrm{PML}$, focusing on current trends in antiviral T cell immunity in non-lymphoid organs, including the CNS. Advances in our understanding of polyomavirus lifecycles, viral and host determinants of persistent infection, and T cell-mediated immunity to viral infections in the CNS warrant revisiting polyomavirus CNS infection in the mouse as a bona fide animal model for JCV-PML.

Keywords: progressive multifocal leukoencephalopathy, JC virus, natalizumab, mouse model, polyomavirus, tissue-resident memory T cells

\section{INTRODUCTION}

The human JC polyomavirus (JCV) persists silently in $>50 \%$ of the healthy adult population, with recent evidence suggesting an even higher prevalence $(1,2)$. Seroepidemiological studies indicate that individuals are first exposed to JCV in late adolescence (3). Based on detection of JCV in tonsils and sewage, the virus is likely acquired via respiratory and/or fecal-oral transmission routes (4-6). JCV was discovered in 1971 as the etiologic agent of progressive multifocal leukoencephalopathy (PML) (7), a lifethreatening demyelinating disease of the central nervous system (CNS) resulting from lytic infection of oligodendrocytes $(8,9)$. PML was first described in 1958 in patients with chronic lymphocytic leukemia and Hodgkin's lymphoma (10), and has since been diagnosed in individuals immunosuppressed by a variety of hematological malignancies. Before the advent of highly active antiretroviral therapy (HAART), approximately $5 \%$ of individuals afflicted with HIV/AIDS developed PML, such that PML became regarded as an AIDS-associated disease (11). Profound immunosuppression, however, is not an essential prelude to PML. PML is seen in HIV-negative individuals with occult or minimal immunosuppression caused by old age, chronic liver or kidney disease, untreated dermatomyositis, and idiopathic $\mathrm{CD}^{+}$or $\mathrm{CD} 8^{+}$ lymphopenia (12). No effective anti-JCV agents are currently available, and the prognosis for PML is poor (13). Recently, PML has emerged in patients receiving humoral immunomodulatory agents for autoimmune diseases and inflammatory disorders.

In 2005, a trilogy of articles in the New England Journal of Medicine described PML in patients with relapsing-remitting multiple sclerosis (MS) and Crohn's disease given the monoclonal antibody natalizumab (Tysabri ${ }^{\circledR}$ ) (14-16). Recent studies report that the risk of PML increases with duration of natalizumab therapy and is as high as 11.1 cases per 1000 patients in MS patients seropositive for JCV, $>24$ months of the monthly infusion therapy, and a history of immunosuppression (17). Most MS treatment regimens were designed to reduce autoreactive immune responses. Natalizumab is a humanized antibody against $\alpha_{4}$ integrin $(\mathrm{CD} 49 \mathrm{~d})$, which complexes with the integrins $\beta_{1}$ (to form very late antigen4 , VLA- 4 ) or $\beta_{7}$ on the surface of activated T cells (18). VLA-4 and $\alpha_{4} \beta_{7}$ enable $\mathrm{T}$ cells to traffic to sites of infection/inflammation or to mucosal tissues, respectively. VLA- 4 and $\alpha_{4} \beta_{7}$ are required for $\mathrm{T}$ cell extravasation by mediating leukocyte arrest at activated vascular endothelium expressing the VLA-4 ligand vascular cell adhesion molecule 1 (VCAM-1) or the $\alpha_{4} \beta_{7}$ ligand mucosal addressin cell adhesion molecule (MAdCAM-1). Supporting the hypothesis that natalizumab-mediated VLA-4 blockade impairs CNS immune surveillance is an early study showing that a cohort of 23 MS patients receiving natalizumab had decreased counts of $\mathrm{CD}^{+}$and $\mathrm{CD}^{+}{ }^{+} \mathrm{T}$ cells, $\mathrm{CD} 19^{+} \mathrm{B}$ cells, and $\mathrm{CD} 138^{+}$plasma cells 
in the CSF compared to 35 untreated MS patients and 16 patients with other neurological diseases. Of 14 patients available for sixmonth followup after cessation of natalizumab therapy, all but one had decreased counts in each of these lymphocyte populations; the one exception being a patient having a modest elevation in $\mathrm{CD} 4^{+}$ and $\mathrm{CD}^{+} \mathrm{T}$ cell counts coincident with a clinical MS replase (19). Other monoclonal antibody-based immunomodulatory therapies, including efalizumab (anti-LFA-1, for severe plaque psoriasis) and rituximab (anti-CD20, for B cell lymphoma), have been shown to put patients at risk for PML; because of this risk, efalizumab was taken off the market despite its efficacy in reducing rejection in kidney transplant recipients (20). With development of more intense steroid-avoidance immunosuppressive agents in transplantation medicine, there is concern that the incidence of PML may also rise in this patient population, as has happened for BK virus (BKV)associated nephropathy. Recent evidence suggests that inadequate $\mathrm{T}$ cell-mediated surveillance for JCV-infected CNS glial cells is the common mechanism among immunosuppressive regimens conferring susceptibility for PML. As discussed above, natalizumab interferes with trafficking of circulating effector $T$ cells into the CNS. Rheumatoid arthritis patients receiving rituximab show marked $\mathrm{T}$ cell depletion, particularly in the $\mathrm{CD} 4^{+} \mathrm{T}$ cell compartment, which is associated with clinical response (21). B celldepletion therapies, such as rituximab, may affect $T$ cell responses by depleting B cell-derived cytokines/chemokines, by eliminating $\mathrm{B}$ cells in their capacity as professional antigen-presenting cells to activate $\mathrm{CD} 4^{+} \mathrm{T}$ cells, or, possibly, by limiting availability of immune complexes to cross-present antigens to $\mathrm{CD}^{+} \mathrm{T}$ cells by $\mathrm{Fc} \gamma \mathrm{R}^{+}$dendritic cells (22). Immune reconstitution by HAART for AIDS or plasma exchange for monoclonal antibody therapy is the recommended treatment option for PML (23). Such regimens predispose patients to a rapid, robust, and often fatal influx of circulating leukocytes into the CNS termed immune reconstitution inflammatory syndrome (IRIS); paradoxically, these treatments can accentuate PML lesions, cause relapse of autoimmune disease or, in the case of organ transplant recipients, lead to graft rejection (24).

In addition to underlying depressed or altered immune function, viral determinants may also increase PML risk and/or disease severity. Mutations resulting in single amino acid substitutions in the host cell receptor binding domain of the viral capsid protein VP1 and rearrangements/deletions in the non-coding control region (NCCR) were found in most JCV sequences from cerebrospinal fluid (CSF) of PML patients (25-28). These mutations may constitute necessary viral determinants for PML and underlie the sharp discrepancy between the high prevalence of JCV infection and the low incidence of PML. Recent work demonstrated that rearranged NCCRs conferred increased early viral gene expression and DNA replication capability in glial cells (29). An important role for the JCV capsid protein in CNS tropism is supported by evidence that a hybrid virus containing the early genes of the monkey polyomavirus, SV40, and the late genes of the PML-JCV (Mad-1 strain) acquired the more restricted host range of JCV; i.e., the ability to infect human fetal glial cells but not monkey cells, and to hemagglutinate human type $\mathrm{O}$ red blood cells (30). Use of JCV VP1 virus-like particles (VLPs) further suggested that the PML-associated JCV capsid mutations alter viral tropism, retaining virion binding specificity for CNS glial cells but not to other non-CNS cell types, and differing from wild type VLPs in glycan specificity (25). However, pseudoviruses with these VP1 mutations failed to transduce glial cells, raising the possibility that these CSF VP1 variants are non-infectious (31). Whether these VP1 variants confer neurovirulence to JCV, and whether JCV acquires these VP1 mutations in the periphery or after entry into the brain, remain to be determined.

Several lines of evidence suggest that humoral immunity selects VP1 mutant polyomaviruses. Exposure of a library of VP1mutagenized SV40 variants to a neutralizing monoclonal antibody selected viruses with mutations in solvent-exposed loops of VP1 that were resistant to neutralization by this antibody (32). BKV serotypes have been shown to vary in their level of crossrecognition by neutralizing antibodies generated by VLP immunization (33). Interestingly, BKV isolates from kidney transplant patients with nephropathy and viremia also had a high frequency of VP1 substitutions (34). These findings raise the possibility that VP1-specific neutralizing antibody responses select variant polyomaviruses with mutations in VP1 that enable escape from antiviral humoral immunity. Whether $\mathrm{T}$ cell immunosuppression/modulation favors neutralizing antibody-driven selection of such polyomavirus escape variants is unknown.

Progress in understanding pathogenesis of JCV-induced PML and developing effective therapeutic approaches is handicapped by the low number of PML cases, inadequate understanding of risk factors (with only three broad risk factors described to date for natalizumab-treated MS individuals - JCV seropositivity, prior immunosuppression, and >2-years of therapy), and heterogeneity among PML patients (e.g., differences in immunosuppression regimens, HLA type, age, and gender). Additional obstacles include consistent patient compliance in clinical studies, under-reporting and under-recognition of the disease, and the rapidity of disease progression following diagnosis (35). Because JCV replicates only in humans, we have limited understanding of the pathogenesis of PML and the immune mechanisms needed to keep persistent polyomavirus infection in check. Studying the evolution of PML pathology rather than the endpoint of disease when PML is diagnosed is essential for identifying factors that predispose only a small fraction of immunosuppressed individuals and those receiving immunomodulatory therapy to PML.

An animal model of polyomavirus-induced CNS disease that mimics pathologic hallmarks of PML would circumvent these obstacles and enable us to address important unanswered questions, including:

1. Which facets of innate and adaptive immunity control JCV infection in the brain and how does immunosuppression/immunomodulation interfere with this control?

2. Are there circumstances in which antiviral immune surveillance in the CNS may prove pathological rather than protective?

3. Does the pathogenesis of PML vary with different immunomodulatory regimens?

4. How/when does JCV traffic to the CNS?

5. When are PML-associated viral mutations acquired and do they confer neurotropism/neurovirulence to JCV? Are these mutations the result of immune selection/evasion? 
6. Why are individuals treated with humoral immune modulatory agents susceptible to JCV encephalitis but not to encephalitides caused by other persistent microbial pathogens (e.g., toxoplasmosis, HSV-1)?

A tractable small animal model of CNS infection by a natural host polyomavirus will provide insight into PML risk factors, mechanisms of disease, and provide a preclinical model to evaluate candidate antiviral agents. Here, we review current literature on $\mathrm{T}$ cell-mediated control of viral infections in non-lymphoid organs, including the CNS, describe potential mechanisms to dampen $\mathrm{T}$ cell function in the setting of persistent CNS infection, and advocate application of the mouse polyomavirus (MPyV) model to understand immune control of polyomavirus infection in the CNS.

\section{EVIDENCE THAT JCV-SPECIFIC T CELLS CONFER PROTECTION FROM PML}

Effective immunity to viruses typically depends on $\mathrm{CD}^{+} \mathrm{T}$ cells and their ability to directly target and kill virally infected cells. Accordingly, presence of detectable JCV-specific $\mathrm{CD}^{+} \mathrm{T}$ cells in peripheral blood correlates with improved prognosis and survival in PML patients (36-38), whereas anti-JCV humoral responses do not $(39,40)$. In $\mathrm{HIV}^{+}$patients, a detectable level of JCV-specific CD8 ${ }^{+}$T cells was coincident with a higher number of $\mathrm{CD}^{+} \mathrm{T}$ cells (41), the presence of which in peripheral blood has been positively correlated with PML survival (42). The dominant HLA-A2-restricted $\mathrm{CD}^{+} \mathrm{T}$ cell epitopes found in JCV-seropositive individuals are directed to determinants corresponding to VP1 residues 100-108 (p100) and 36-44 (p36), with the former being the dominant specificity (43). Staining with HLA-A ${ }^{\star} 0201-V P 1$ p36 and -VP1p100 tetramers showed that these JCV-specific $\mathrm{CD}^{+} \mathrm{T}$ cells have an effector-memory phenotype (CD62 $\mathrm{L}^{\text {lo }} \mathrm{CD} 45 \mathrm{RA}^{-} \mathrm{CD} 49 \mathrm{~d}^{\text {hi }}$ ) and can be found in the PBMCs of healthy individuals, perhaps contributing to the overall low incidence of PML $(44,45)$. Indeed, when measured early after PML diagnosis, the presence of JCV-specific CD8 ${ }^{+}$PBMCs predicted control of PML, while the absence of these cells predicted active PML progression (41). In $\mathrm{HIV}^{+} \mathrm{PML}$ patients, $\mathrm{CD}^{+} \mathrm{T}$ cells can be found infiltrating the brain and co-localizing with infected oligodendrocytes at the edges of PML lesions (46) where the $\mathrm{T}$ cell receptor ligands MHC I and II are upregulated (47). Taken together, these findings suggest that JCV infection is predominantly controlled by $\mathrm{CD} 8^{+} \mathrm{T}$ cells.

Studies of human JCV-specific T cell responses have been predominantly based on analysis of PBMCs. Because few JCV-specific cells can be isolated from healthy individuals and PML patients, JCV-specific T cells are generally subjected to extended expansion and selection in tissue culture, which may obscure conclusions regarding their in vivo phenotype and function, as highlighted by an early study showing long-term in vitro $\mathrm{T}$ cell proliferation can profoundly underestimate frequencies of antigen-specific $\mathrm{T}$ cells in vivo (48). Although the development of MHC I tetramers for detecting JCV-specific $\mathrm{CD}^{+}{ }^{+} \mathrm{T}$ cells has improved quantification of these cells, the low incidence of PML coupled with few defined HLA class I-restricted JCV epitopes limits direct analyses of JCV-specific CD8 ${ }^{+} \mathrm{T}$ cells in PML patients. Additionally, analysis of CNS-infiltrating T cells is hampered because PML brain lesions show minimal inflammation, which may be due to the patient's immunosuppressive state and to the late stage of disease at time of diagnosis. Only one study has analyzed CNS-infiltrating JCV-specific T cells directly ex vivo by flow cytometry using a fresh brain biopsy of a natalizumab-treated MS patient with a pronounced T cell infiltrate secondary to IRIS (49). Examination of immune surveillance prior to diagnosis of PML is limited to CSF samples, which does not necessarily reflect immune infiltrates in the brain parenchyma (19). Given the limited data available regarding the type, function, and location of cellular infiltrates in the brain parenchyma, little is known about the status of immune surveillance in the CNS for JCV-infected cells prior to PML and during its progression.

Insights into the evolution and maintenance of JCV-specific $\mathrm{T}$ cell responses in the human CNS would greatly benefit from a mouse model of polyomavirus CNS infection. Use of this animal model would provide insight into the kinetics of antipolyomavirus immune surveillance in the CNS, how immune suppression alters this surveillance and the incidence of neuropathology. Inbred strains of mice simplify identification of viral peptide $\mathrm{T}$ cell epitopes, which is essential to monitor the magnitude, phenotype, and function of virus-specific T cells. Incisive identification of determinants of effective CNS immune responses can be achieved using transgenic mice, mice with targeted genetic deletions, and antibody-mediated blockade of key interactions or deletion of specific cell types. Mouse models of viral infections can be optimized for pathogen dose and time postinfection to yield higher numbers of immune cells to study directly ex vivo. Furthermore, immune cells can be isolated from mouse tissues, providing insight into potential differentiation/regulation of cells in situ in the CNS. Such studies using mouse models are underpinned by a newfound appreciation that circulating $\mathrm{T}$ cells are phenotypically and functionally distinct from those resident in non-lymphoid tissues.

\section{CNS-RESIDENT CD8 ${ }^{+}$MEMORY T CELLS}

Memory $\mathrm{CD}^{+} \mathrm{T}$ cells are heterogeneous in phenotype, differentiation, and function; these parameters are linked to their migration patterns and anatomic location (50). Since the original description of non-lymphoid organ-homing "effector memory" versus lymphoid organ-homing "central memory" populations (51), evidence is quickly accumulating that memory $\mathrm{T}$ cell heterogeneity is integrated with tissue residence; i.e., depending on their tissue localization, memory $\mathrm{T}$ cells vary in expression of chemokine receptors, adhesion molecules, and effector capabilities (52). Effector-memory T cells are now thought to be comprised of circulating and non-circulating subsets. The latter "tissue resident" memory $\mathrm{T}$ cells or $\mathrm{T}_{\mathrm{rm}}$ cells are distinguished from circulating effector-memory cells by upregulation of CD69 and granzyme $\mathrm{B}$ (canonically indicative of TCR activation and cytotoxic effector capability, respectively) and cell surface expression of the $\alpha_{\mathrm{E}}(\mathrm{CD} 103) \beta_{7}$ integrin. Because the $\alpha_{\mathrm{E}} \beta_{7}$ complex binds to Ecadherin, CD103 expression implicates a role for these integrins in $\mathrm{T}$ cell retention in epithelium. Recent work showed that CD103 is variably expressed by CD8 ${ }^{+} \mathrm{T}_{\mathrm{rm}}$ cells in different tissues, suggesting that CD103 per se is not a signature $\mathrm{T}_{\mathrm{rm}}$ cell marker (53). 
CD69 directly antagonizes expression of $\mathrm{S}_{1} \mathrm{P}_{1}$, a sphingosine-1phosphate receptor expressed by $\mathrm{T}$ cells to enable their egress from peripheral lymphoid organs (54); $\mathrm{S}_{1} \mathrm{P}_{1}$ downregulation is essential for retention of $\mathrm{T}$ cells in tissues (53). TGF- $\beta$ is a key mediator of $\mathrm{CD} 103$ expression by activated $\mathrm{CD} 8^{+} \mathrm{T}$ cells in the skin and intestinal mucosa, as well as the CNS, and TGF- $\beta$ may also be involved in upregulating CD69 (55-57). $\mathrm{CD}^{+} \mathrm{T}_{\mathrm{rm}}$ cells persist long-term in the skin and in mucosal sites such as the respiratory tract, female reproductive tract, and gut (58-61), and for the intestine at least, maintenance of $\mathrm{CD}^{+} \mathrm{T}_{\mathrm{rm}}$ cells is antigen-independent (56). A rapidly expanding body of literature demonstrates that $\mathrm{T}_{\mathrm{rm}}$ cells contribute to host defense to bacterial and viral reencounter at mucosal and epidermal sites $(62,63)$.

Antiviral $\mathrm{CD}^{+} \mathrm{T}$ cells also establish residence in the CNS but appear to differ in their requirements for function and survival compared to those in extra-CNS non-lymphoid tissues. Intracranial (i.c.) inoculation of mice with vesicular stomatitis virus (VSV), an acutely infecting pathogen, resulted in the progressive accumulation in the brain of $\mathrm{CD} 103^{+} \mathrm{CD} 69^{\text {hi }}$ granzyme $\mathrm{B}^{\text {hi }}$ virus-specific $\mathrm{CD}^{+} \mathrm{T}_{\mathrm{rm}}$ cells, whose maintenance was antigen-independent and required CD103 (64). Differences in virus interactions with their hosts (e.g., levels of antigen persistence, cytopathic/non-cytopathic cell fate and host cell tropism) will undoubtedly influence the establishment, maintenance, and function of CNS-resident memory $\mathrm{T}$ cells and their immunosurveillance efficacy for infected cells.

The presence of CNS-infiltrating $\mathrm{CD}^{+}{ }^{+} \mathrm{T}$ cells circumscribing demyelinated lesions was associated with improved clinical outcome in HIV/AIDS-related PML patients (46). This association has been extended to explain the development of PML in MS patients receiving natalizumab. MS progression is characterized by two distinct phases: a primary relapsing-remitting stage in which repetitive and acute infiltration of the brain by myelinreactive $\mathrm{T}$ cells occurs and inflammation resolves; and a secondary progressive phase in which little inflammation is observed but lesions of demyelination and functional disability worsen (65). Because natalizumab acts to exclude circulating activated $\mathrm{T}$ cells from the CNS, it is possible that no JCV-specific T cells infiltrate the brains of natalizumab-treated MS patients with active JCV replication. MS is a difficult disease to diagnose, and patients likely experience acute autoreactive inflammation prior to initiation of natalizumab therapy. Myelin-reactive inflammation may render the blood-brain barrier "permeable" to JCV (as free virions or via infected cells, as discussed below) as well as JCV-reactive T cells. In this connection, it merits noting that natalizumab is typically not the first-line treatment option for MS. If JCV infection in the brain and a subsequent $\mathrm{T}$ cell infiltration occurred prior to the administration of natalizumab therapy, CNS-infiltrating JCVspecific cells would not be affected and could potentially establish a resident memory population. Based on data from various animal models of tissue resident memory $\mathrm{T}$ cells, in the context of persistent infection in the CNS functional JCV-specific $\mathrm{T}_{\mathrm{rm}}$ cells might survive long-term or be driven to dysfunction and deletion. In the former case, JCV-specific $\mathrm{T}_{\mathrm{rm}}$ cells would be protective, whereas in the latter situation, exhausted $\mathrm{T}_{\mathrm{rm}}$ cells may predominate and fail to limit the number of infected oligodendrocytes. Natalizumab, then, would prevent replenishment of CNS-infiltrating
JCV-specific $\mathrm{T}$ cells from circulating blood and result in deficient $\mathrm{T}$ cell-mediated immune surveillance for infected glial cells. These alternate scenarios may help explain the rarity of PML even in immunocompromised individuals. Knowing the longevity of functional $\mathrm{T}_{\mathrm{rm}}$ cells in the CNS, which would be most readily studied using a mouse model of polyomavirus CNS infection, may help explain the increased risk of PML with long-term natalizumab therapy.

\section{THE INHIBITORY PD-1 RECEPTOR BALANCES IMMUNITY AND IMMUNOPATHOLOGY IN THE CNS}

The brain is widely considered to be an "immune-privileged" organ. Until recently, immune privilege was thought to result from a complete exclusion of the immune effector cells; however, healthy immune-privileged sites are actually subject to active immune surveillance, requiring the functionality of immune effector cells be tightly managed to protect vital, non-renewable tissues (66). Regulating cells of the immune response typically depends on the balance of activating and inhibitory signals. PD-1 (CD279), a CD28-family molecule, is expressed by activated T cells and counters the activation signaling cascade initiated by TCR ligation. PD-1 expression is significantly elevated on JCV-specific CD4 ${ }^{+}$ and $\mathrm{CD}^{+} \mathrm{T}$ cells from peripheral blood of PML patients (67). PD-1 is induced by TCR signaling and its expression is maintained in settings of persistent antigenic stimulation such as chronic viral infection, cancer, and autoimmunity. PD-1 binds to two ligands, PD-L1 (also called B7-H1; CD274) and PD-L2 (CD273) that differ in expression patterns: PD-L1 is broadly expressed by hematopoietic and parenchymal cells; and PD-L2 is inducibly expressed on DCs and macrophages (68). Recent work indicates that variable levels of PD-1 signaling translates to differentially dampening $\mathrm{T}$ cell functions, with low PD-1 levels inhibiting TNF- $\alpha$, IL-2 production, and cell proliferation and higher levels inhibiting cytotoxicity and IFN- $\gamma$ production (69). Sustained high PD-1 expression in the setting of chronic viremic infection mediates exhaustion of virus-specific $\mathrm{CD}^{+} \mathrm{T}$ cells $(70)$.

Although PD-1 regulation of $\mathrm{T}$ cells has been intensively investigated for systemic persistent viral infections, surprisingly little is known about its role in viral encephalitis. In mouse cytomegalovirus encephalitis, brain-localized $\mathrm{CD} 8^{+} \mathrm{T}$ cells express PD-1, activated microglia and astrocytes express its ligand (PD-L1), and PD-1 blockade in microglia/astrocytes and $\mathrm{CD}^{+}$ $\mathrm{T}$ cell co-cultures increases IFN- $\gamma$ production $(71) . \mathrm{CD}^{+} \mathrm{T}$ cells infiltrating the CNS of mice persistently infected by the gliatropic mouse JHM coronavirus are also PD- $1^{\text {hi }}$. IFN- $\gamma$ receptor signaling by oligodendrocytes induces their expression of PD-L1 (72), which, in turn, limits effector activity of PD-1 hi JHM-specific $\mathrm{CD}^{+} \mathrm{T}$ cells. Engagement of these PD- ${ }^{\text {hi }}$ cells with PD-L1 ${ }^{+}$ oligodendrocytes prevents $\mathrm{T}$ cell-mediated axonal bystander damage, but does so at the cost of negating viral clearance $(73,74)$. Interestingly, CNS infection by VSV, a neurotropic and nondemyelinating pathogen, is associated with robust virus-specific $\mathrm{CD}^{+} \mathrm{T}$ cells brain infiltrates, but these T cells lack PD-1 expression (64). PD-1 is elevated on $\mathrm{CD}^{+} \mathrm{T}$ cells from PML patients (67). These studies raise the possibility that PD-1 upregulation is a property of $\mathrm{T}$ cells responding to gliatropic viral infections. These data are in line with the concept that PD-1 inhibits 
T cell-mediated immunopathologic demyelination, a concept supported by studies documenting a protective role for PD-1 in the experimental autoimmune encephalomyelitis (EAE) mouse model of MS (75-78).

Because persistent polyomavirus infection establishes a lowlevel antigen setpoint, PD-1 upregulation by polyomavirusspecific $\mathrm{T}$ cells is unexpected, and suggests that sustained strong TCR signaling may not be essential for PD-1 expression in the brain. In HIV-positive individuals, $\mathrm{PD}-1$ expression is higher on $\mathrm{T}$ cells in the CSF than those in blood, despite viral RNA levels being lower in the CSF (79). Certain common $\gamma$-chain cytokines (IL-2, IL-7, IL-15, and IL-21) and type I IFNs have been shown to induce and maintain PD-1 expression on TCR-activated cells (80-82); and type I and type II IFNs, IL-6, IL-2, IL-7, and IL-15 upregulate PD-L1 (83). With regard to MPyV, IFN- $\beta$ transcripts have been shown to be elevated in brains of mice given MPyV i.c. (84). This raises the possibility that the polyomavirus-induced proinflammatory environment in the CNS could complement low/intermittent TCR engagement to upregulate PD- 1 on antiviral $\mathrm{T}_{\mathrm{rm}}$ cells in the brain. A polyomavirus CNS infection animal model would enable investigation of the mechanisms of PD-1 upregulation by brainresident, virus-specific $\mathrm{T}$ cells and the functional role(s) of PD-1 expression by $\mathrm{T}$ cells in the CNS.

\section{USING JCV TO MODEL PML IN ANIMALS}

A tractable animal model of PML requires sufficient similarities between hallmarks of disease in humans, including cell targets for viral replication, mechanisms of immune control, associated risk factors, and neuropathology. Until recently, however, attempts to model PML in mice utilizing the etiologic agent of PML, JCV, have been handicapped by the tight species specificity of Polyomaviridae. Lacking a viral DNA polymerase, polyomaviruses rely on the host cell DNA polymerase apparatus to replicate their genomes, and thus have devised strategies to override cell cycle checkpoints (85). The species restriction for polyomaviruses is controlled at the level of binding by the host cell DNA polymerase $\alpha$-primase complex to the viral origin of replication $(86,87)$, a molecular interaction reflective of the co-evolution of each Polyomaviridae family member with a particular vertebrate species. Non-productive infection by polyomaviruses can result in the integration of the viral genome into the host chromosomal DNA resulting in tumor formation (88-90). Accordingly, experiments involving i.c. inoculations of non-human primates and mice with JCV resulted in non-productive infection and development of astrocytomas or glioblastomas but not PML-like disease (9196). Transgenic mice containing the early region of JCV in all cells predominantly expressed $\mathrm{T}$ antigens in oligodendrocytes and exhibited a dysmyelination phenotype, but did not recapitulate the demyelination associated with JCV encephalitis in human (97). These findings have largely obviated the use of JCV infection in unmanipulated mice to model PML.

To partially preserve the species specificity of JCV infections in animal hosts, attempts have been made to use JCV in humanized mouse models. Low levels of JCV DNA were detected in the urine and blood of JCV-infected NOD/SCID/IL$2 \mathrm{R} \alpha^{-1-}$ mice reconstituted with human fetal bone marrow, thymus, and liver, as were low numbers of IFN- $\gamma$-producing $\mathrm{T}$ cells (98). In the absence of human CNS tissue to provide cellular targets for JCV replication, this system cannot recapitulate PML. This obstacle has recently been overcome. Goldman and colleagues created human glial chimeric mice by engrafting human bipotential oligodendrocyte-astrocyte progenitor cells into congenitally hypomyelinated $\mathrm{Rag} 2^{-/-} \mathrm{Mbp} \mathrm{p}^{\text {shi/shi }}$ neonatal mice, resulting in efficient colonization of the mouse brain with human astrocytes and oligodendrocytes and myelination $(99,100)$. Using these human glial chimeric mice, Kondo et al. recently reported that intracerebral delivery of Mad-1 JCV resulted in early widespread productive infection of the engrafted human astrocytes, focal demyelination, and gliosis (101). Only rare oligodendrocytes were infected early postinfection, but at late timepoints large numbers of $\mathrm{T}$ antigen ${ }^{+} \mathrm{VP} 1^{-}$oligodendrocytes were detected. These findings raise the provocative possibility that demyelination may in large part be accounted for by deficient trophic support for oligodendrocytes resulting from death of productively infected astrocytes rather than by elimination of oligodendrocytes by lytic JCV infection. Another notable finding in this study was the rapid emergence of a sizeable number of VP1 genomic mutations, with at least two previously seen in JCV isolates from PML patients. Thus, astrocytes may be a major site for emergence of neurovirulent VP1 variant viruses. This chimeric mouse model represents an important advance toward understanding mechanisms of pathogenesis of demyelination; however, infection of these human glia-engrafted mice cannot provide insight into the role of JCV-specific immune responses in the CNS.

\section{JCV ENTRY TO THE CNS}

A major unresolved question is the mode of transit of JCV to the CNS; i.e., as free virus and/or via infected "Trojan Horse" cells. Deep sequencing of JCV NCCR in matched urine, plasma, and CSF samples from a PML patient provides strong support for a hematogenous route for viral dissemination (102), a conclusion in line with earlier evidence that VP1 mutations are detected in blood and CSF, but not in urine, of PML patients (27). Human brain microvascular endothelial cells have been demonstrated to be permissive for JCV infection, a finding supporting the possibility that JCV may cross the blood-brain barrier by infecting endothelial cells (103). In favor of cell-based blood-to-brain carriage is an early study reporting detection of JCV and BKV DNA in peripheral blood leukocytes from healthy adults (104). Subsequent work has focused attention on B cells and/or CD34 ${ }^{+}$ hematopoietic progenitor cells (HPCs) as candidate vehicles for conveying JCV to the CNS. JCV DNA, as well as expression of $\mathrm{T}$ antigen and VP1, has been observed in HPC cell lines, B cell lines and primary $\mathrm{B}$ cells infected in vitro by high-dose virus inocula, and rare JCV DNA ${ }^{+} \mathrm{B}$ cells have been detected in PBMCs from a PML patient $(4,105)$. In addition, the rearranged NCCR contains multiple binding sites for the Spi-B and NF1-X, transcription factors that enhance JCV replication and are expressed by B cells, HPCs, and glial cells [reviewed in Ref. (13)]. Notably, gene expression of unfractionated blood, and sorted $\mathrm{CD} 19^{+} \mathrm{B}$ cells, and $\mathrm{CD} 34^{+}$HPCs from MS patients receiving natalizumab revealed upregulation of genes involved in $\mathrm{B}$ cell activation and differentiation, including Spi-B $(106,107)$. These findings are in 
line with a proposal that upregulation of specific transcription factors that bind JCV NCCR underlie a resurgence of JCV replication in natalizumab-treated individuals $(108,109)$. Because B cells are endowed with the recombination apparatus enabling $\mathrm{V}(\mathrm{D}) \mathrm{J}$ recombination of immunoglobulin gene segments, $B$ cells have also been proposed to provide an environment conducive for JCV genome recombination and/or rearrangement (13), despite the absence of RAG-dependent recombination signal sequence motifs in the JCV genome. Whether B cells are truly capable of supporting JCV replication remains to be demonstrated, particularly in light of recent data suggesting that B cells may carry intact input JCV virions and transfer them to susceptible glial cells (110). CD49d antibody-mediated blockade in mice and non-human primates is associated with elevated circulating $\mathrm{CD} 34^{+}$cells, an observation recapitulated in natalizumab-treated MS patients (111-113). In humans, natalizumab has also been reported to mobilize CD34 ${ }^{+}$ cells, pre-B cells, and B cells into the circulation $(114,115)$. These observations give additional impetus to the value of an immunocompetent mouse model of PML to define the cellular vehicle by which JCV is transported to the brain parenchyma, the status of JCV replication in these cells, and investigating the possible role of VLA-4 blockade in promoting JCV spread to the CNS.

\section{MPyV AS A MODEL TO UNDERSTAND HUMAN POLYOMAVIRUS PATHOGENESIS}

Mouse polyomavirus, the founding member of the Polyomaviridae family, is structurally and genomically similar to JCV, BKV, and SV40 polyomaviruses. All polyomaviruses consist of a doublestranded, covalently closed circular $\sim 5$-kb DNA genome encapsidated by a non-enveloped icosahedral shell composed of 72 pentameric VP1 capsomers. The genomes of all polyomaviruses have a $\sim 500$-bp NCCR containing the origin of replication bidirectional promoters separating the genome into early and late genes, with respect to the onset of viral DNA synthesis: an early region encoding the non-structural small $\mathrm{T}$ and large $\mathrm{T}$ antigens; and a late region encoding the viral capsid proteins VP1, VP2, and VP3. Unlike JCV, the MPyV genome does not encode an agnoprotein in its late region and contains an additional early region sequence encoding the non-structural middle $\mathrm{T}$ antigen, which mediates cellular transformation and tumor induction (116).

Mouse polyomavirus also resembles BKV and JCV with regard to infectivity and interaction with the immune system. Epidemiologic surveys of wild mice showed that MPyV, like its human counterparts, is a widely prevalent, harmless pathogen in its natural host reservoir $(117,118)$. MPyV infects a variety of epithelial and mesenchymal cells (119), macrophages, and DCs, but not lymphocytes (120). Neuroectodermal lineage cells were stated to be non-permissive for MPyV replication (119), but evidence for this host cell range restriction is lacking. As described above for PML-JCV variants, strains of MPyV carrying single amino acid differences in VP1 differed in glycan specificity, which in turn altered tissue tropism and pathogenesis (121, 122). Similar to reports of long-term persistence of JCV and BKV DNA in a variety of human tissues $(6,109,123)$, MPyV DNA has been detected in multiple organs, including those of the CNS, kidney, and bone marrow, for months after acute infection in both immunodeficient and immunocompetent mice (124-126), with decline in immunologic status setting the stage for viral reactivation. Both human and mouse polyomavirus infections elicit potent neutralizing antibody responses directed toward VP1 that inhibit capsid binding to sialyated glycolipid and glycoprotein receptors on host cells. MPyV persistently infects mice in the presence of virus-neutralizing VP1 Abs (127). Similarly, neutralizing Abs against JCV, typically present in most individuals, confer no protection against PML (128). While neither human nor mouse polyomaviruses cause overt disease in immunocompetent adult hosts, immunosuppression provides an opportunity for both human and mouse polyomaviruses to induce a variety of disease processes (129). MPyV-induced rejection of mouse renal allografts has been used to understand how immunosuppression alters the evolution of polyomavirus-associated nephropathy and how the immune response to polyomavirus infection contributes to allograft injury $(130,131)$.

Mouse polyomavirus replication causes disease in the CNS. Primary glial cells derived from mouse corpus callosum showed that type 1 astrocytes, but neither type 2 astrocytes nor oligodendrocytes, were infected by MPyV (132). This was not the case in vivo as infection of congenitally athymic mice with $\mathrm{MPyV}$ resulted in wasting disease and spinal cord demyelination consequent to infection of oligodendrocytes (133). Demyelinated lesions were not observed in euthymic mice, emphasizing the role of immune suppression in disease progression. Infected nude mice eventually developed hind limb paralysis, which was attributed to vertebral bone tumors rather than PML-like disease (134, 135). In each of these early studies, mice were infected by a natural route of transmission via contamination from a neighboring mouse room. In a study involving i.c. inoculation of adult nude mice with the LID strain of MPyV, which caused fatal kidney and brain hemorrhages in newborn $\mathrm{C} 3 \mathrm{H}$ mice (122), paralysis and vertebral tumors developed in the absence of demyelination (135). This publication was largely responsible for the de facto moratorium on use of MPyV CNS infection as a model for PML. Interestingly, molecular modeling showed that the valine-to-alanine substitution at VP1 amino acid 296 in LID was orthologous to ${ }^{269}$ VP1 of JCV, where a serine to phenylalanine/tyrosine mutation was among the frequent mutations detected in VP1 genes of JCV isolates from PML patients (26). Although an MPyV-mouse model of CNS disease cannot reproduce all aspects of JCV-PML pathology in humans, just as significant aspects of other mouse models do not fully recapitulate human disease, new evidence for the existence of tissue-specific protective antiviral T cells and recent work from our laboratory using i.c. inoculation of $\mathrm{MPyV}$ in tumor-resistant mice, suggest that $\mathrm{MPyV}$ may prove to be an important animal model of polyomavirus-induced CNS demyelination.

\section{CONCLUSION}

Progressive multifocal leukoencephalopathy, a rare complication of immunosuppression, is caused by infection of the CNS by JC virus, a highly ubiquitous and silent human pathogen in healthy individuals. This wide discordance between virus prevalence and disease incidence appears to stem from the coalescence of multiple predisposing factors including viral determinants that alter host cell tropism, host immune determinants that affect CNS 
surveillance for infected glial cells, and variability in the underlying immunosuppressive disease/treatment regimen. Lack of a tractable animal model due to the tight species specificity of Polyomaviridae has stymied efforts to determine the contributions of each factor to PML pathogenesis. Here, we have reviewed the literature describing previous attempts to develop animal models for PML and propose use of mouse polyomavirus to study the interplay between the host immune response and infection in the brain. Significant research using peripheral blood mononuclear cells and autopsy/biopsy tissue from PML patients implicates a role for JCV-specific $\mathrm{T}$ cell responses in disease outcome. The $\mathrm{MPyV}$ encephalitis model should provide insight into mechanisms of JCV-induced demyelination and evolution of protective/pathological immune responses to JCV CNS infection in situ, as well as provide a preclinical platform to evaluate strategies to prevent and control PML.

\section{ACKNOWLEDGMENTS}

The authors were supported by the PML Consortium, LLC (to AEL), and the National Institutes of Health (R01 NS088367 and R01 AI102543 to Aron E. Lukacher; F31 NS083336 to Elizabeth L. Frost).

\section{REFERENCES}

1. Egli A, Infanti L, Dumoulin A, Buser A, Samaridis J, Stebler C, et al. Prevalence of polyomavirus BK and JC infection and replication in 400 healthy blood donors. J Infect Dis (2009) 199(6):837-46. doi:10.1086/597126

2. Berger JR, Houff SA, Gurwell J, Vega N, Miller CS, Danaher RJ. JC virus antibody status underestimates infection rates. Ann Neurol (2013) 74(1):84-90. doi:10.1002/ana.23893

3. Kean JM, Rao S, Wang M, Garcea RL. Seroepidemiology of human polyomaviruses. PLoS Pathog (2009) 5(3):e1000363. doi:10.1371/journal.ppat. 1000363

4. Monaco MC, Atwood WJ, Gravell M, Tornatore CS, Major EO. JC virus infection of hematopoietic progenitor cells, primary B lymphocytes, and tonsillar stromal cells: implications for viral latency. J Virol (1996) 70(10):7004-12.

5. Bofill-Mas S, Girones R. Excretion and transmission of JCV in human populations. J Neurovirol (2001) 7(4):345-9. doi:10.1080/13550280152537210

6. Berger JR, Miller CS, Mootoor Y, Avdiushko SA, Kryscio RJ, Zhu H. JC virus detection in bodily fluids: clues to transmission. Clin Infect Dis (2006) 43(1):e9-12. doi:10.1086/504947

7. Padgett BL, Walker DL, ZuRhein GM, Eckroade RJ, Dessel BH. Cultivation of papova-like virus from human brain with progressive multifocal leucoencephalopathy. Lancet (1971) 1(7712):1257-60. doi:10.1016/S0140-6736(71) 91777-6

8. Itoyama Y, Webster HD, Sternberger NH, Richardson EP Jr, Walker DL, Quarles RH, et al. Distribution of papovavirus, myelin-associated glycoprotein, and myelin basic protein in progressive multifocal leukoencephalopathy lesions. Ann Neurol (1982) 11(4):396-407. doi:10.1002/ana.410110414

9. Zu Rhein GM. Association of papova-virions with a human demyelinating disease (progressive multifocal leukoencephalopathy). Prog Med Virol (1969) 11:185-247.

10. Astrom KE, Mancall EL, Richardson EP Jr. Progressive multifocal leukoencephalopathy; a hitherto unrecognized complication of chronic lymphatic leukaemia and Hodgkin's disease. Brain (1958) 81(1):93-111.

11. Major EO. Progressive multifocal leukoencephalopathy in patients on immunomodulatory therapies. Annu Rev Med (2010) 61:35-47. doi:10.1146/ annurev.med.080708.082655

12. Gheuens S, Pierone G, Peeters P, Koralnik IJ. Progressive multifocal leukoencephalopathy in individuals with minimal or occult immunosuppression. J Neurol Neurosurg Psychiatry (2010) 81(3):247-54. doi:10.1136/jnnp.2009. 187666

13. Ferenczy MW, Marshall LJ, Nelson CD, Atwood WJ, Nath A, Khalili K, et al. Molecular biology, epidemiology, and pathogenesis of progressive multifocal leukoencephalopathy, the JC virus-induced demyelinating disease of the human brain. Clin Microbiol Rev (2012) 25(3):471-506. doi:10.1128/CMR. 05031-11

14. Kleinschmidt-DeMasters BK, Tyler KL. Progressive multifocal leuk9oencephalopathy complicating treatment with natalizumab and interferon $\beta$-1a for multiple sclerosis. $N$ Engl J Med (2005) 353(4):369-74. doi:10.1056/NEJMoa051782

15. Langer-Gould A, Atlas SW, Green AJ, Bollen AW, Pelletier D. Progressive multifocal leukoencephalopathy in a patient treated with natalizumab. N Engl J Med (2005) 353(4):375-81. doi:10.1056/NEJMoa051847

16. Van Assche G, Van Ranst M, Sciot R, Dubois B, Vermeire S, Noman M, et al. Progressive multifocal leukoencephalopathy after natalizumab therapy for Crohn's disease. N Engl J Med (2005) 353(4):362-8. doi:10.1056/NEJMoa051586

17. Bloomgren G, Richman S, Hotermans C, Subramanyam M, Goelz S, Natarajan A, et al. Risk of natalizumab-associated progressive multifocal leukoencephalopathy. N Engl J Med (2012) 366(20):1870-80. doi:10.1056/ NEJMoa1107829

18. von Andrian UH, Engelhardt B. $\alpha 4$ integrins as therapeutic targets in autoimmune disease. N Engl J Med (2003) 348(1):68-72. doi:10.1056/NEJMe020157

19. Stüve O, Marra CM, Jerome KR, Cook L, Cravens PD, Cepok S, et al. Immune surveillance in multiple sclerosis patients treated with natalizumab. Ann Neurol (2006) 59(5):743-7. doi:10.1002/ana.20858

20. Carson KR, Focosi D, Major EO, Petrini M, Richey EA, West DP, et al. Monoclonal antibody-associated progressive multifocal leucoencephalopathy in patients treated with rituximab, natalizumab, and efalizumab: a review from the Research on Adverse Drug Events and Reports (RADAR) Project. Lancet Oncol (2009) 10(8):816-24. doi:10.1016/S1470-2045(09)70161-5

21. Melet J, Mulleman D, Goupille P, Ribourtout B, Watier H, Thibault G. Rituximab-induced $\mathrm{T}$ cell depletion in patients with rheumatoid arthritis: association with clinical response. Arthritis Rheum (2013) 65(11):2783-90. doi:10.1002/art.38107

22. Leon B, Ballesteros-Tato A, Randall TD, Lund FE. Prolonged antigen presentation by immune complex-binding dendritic cells programs the proliferative capacity of memory CD8 T cells. J Exp Med (2014) 211(8):1637-55. doi:10.1084/jem.20131692

23. Clifford DB. Progressive multifocal leukoencephalopathy therapy. J Neurovirol (2014). doi:10.1007/s13365-014-0289-8

24. Johnson T, Nath A. Immune reconstitution inflammatory syndrome and the central nervous system. Curr Opin Neurol (2011) 24(3):284-90. doi:10.1097/ WCO.0b013e328346be57

25. Gorelik L, Reid C, Testa M, Brickelmaier M, Bossolasco S, Pazzi A, et al. Progressive multifocal leukoencephalopathy (PML) development is associated with mutations in JC virus capsid protein VP1 that change its receptor specificity. J Infect Dis (2011) 204(1):103-14. doi:10.1093/infdis/jir198

26. Sunyaev SR, Lugovskoy A, Simon K, Gorelik L. Adaptive mutations in the JC virus protein capsid are associated with progressive multifocal leukoencephalopathy (PML). PLoS Genet (2009) 5(2):e1000368. doi:10.1371/journal. pgen. 1000368

27. Reid CE, Li H, Sur G, Carmillo P, Bushnell S, Tizard R, et al. Sequencing and analysis of JC virus DNA from natalizumab-treated PML patients. J Infect Dis (2011) 204(2):237-44. doi:10.1093/infdis/jir256

28. Pietropaolo V, Videtta M, Fioriti D, Mischitelli M, Arancio A, Orsi N, et al. Rearrangement patterns of JC virus noncoding control region from different biological samples. J Neurovirol (2003) 9(6):603-11. doi:10.1080/714044482

29. Gosert R, Rinaldo CH, Funk GA, Egli A, Ramos E, Drachenberg CB, et al. Polyomavirus $\mathrm{BK}$ with rearranged noncoding control region emerge in vivo in renal transplant patients and increase viral replication and cytopathology. J Exp Med (2008) 205(4):841-52. doi:10.1084/jem.20072097

30. Chen BJ, Atwood WJ. Construction of a novel JCV/SV40 hybrid virus (JCSV) reveals a role for the JCV capsid in viral tropism. Virology (2002) 300(2):282-90. doi:10.1006/viro.2002.1522

31. Maginnis MS, Stroh LJ, Gee GV, O'Hara BA, Derdowski A, Stehle T, et al. Progressive multifocal leukoencephalopathy-associated mutations in the JC polyomavirus capsid disrupt lactoseries tetrasaccharide c binding. MBio (2013) 4(3):e247-213. doi:10.1128/mBio.00247-13

32. Murata H, Teferedegne B, Sheng L, Lewis AM Jr, Peden K. Identification of a neutralization epitope in the VP1 capsid protein of SV40. Virology (2008) 381(1):116-22. doi:10.1016/j.virol.2008.07.032 
33. Pastrana DV, Brennan DC, Cuburu N, Storch GA, Viscidi RP, Randhawa PS, et al. Neutralization serotyping of BK polyomavirus infection in kidney transplant recipients. PLoS Pathog (2012) 8(4):e1002650. doi:10.1371/journal.ppat. 1002650

34. Luo C, Hirsch HH, Kant J, Randhawa P. VP-1 quasispecies in human infection with polyomavirus BK. J Med Virol (2012) 84(1):152-61. doi:10.1002/ jmv.22147

35. Berger JR. The clinical features of PML. Cleve Clin J Med (2011) 78(Suppl 2):S8-12. doi:10.3949/ccjm.78.s2.03

36. Du Pasquier RA, Clark KW, Smith PS, Joseph JT, Mazullo JM, De Girolami U, et al. JCV-specific cellular immune response correlates with a favorable clinical outcome in HIV-infected individuals with progressive multifocal leukoencephalopathy. J Neurovirol (2001) 7(4):318-22. doi:10.1080/ 13550280152537175

37. Koralnik IJ, Du Pasquier RA, Letvin NL. JC virus-specific cytotoxic T lymphocytes in individuals with progressive multifocal leukoencephalopathy. J Virol (2001) 75(7):3483-7. doi:10.1128/JVI.75.7.3483-3487.2001

38. Koralnik IJ, Du Pasquier RA, Kuroda MJ, Schmitz JE, Dang X, Zheng Y, et al. Association of prolonged survival in $\mathrm{HLA}_{-} \mathrm{A} 2^{+}$progressive multifocal leukoencephalopathy patients with a CTL response specific for a commonly recognized JC virus epitope. J Immunol (2002) 168(1):499-504. doi:10.4049/jimmunol. 168.1.499

39. Weber T, Trebst C, Frye S, Cinque P, Vago L, Sindic CJ, et al. Analysis of the systemic and intrathecal humoral immune response in progressive multifocal leukoencephalopathy. J Infect Dis (1997) 176(1):250-4. doi:10.1086/ 514032

40. Guillaume B, Sindic CJ, Weber T. Progressive multifocal leukoencephalopathy: simultaneous detection of JCV DNA and anti-JCV antibodies in the cerebrospinal fluid. Eur J Neurol (2000) 7(1):101-6. doi:10.1046/j.1468-1331.2000. 00009.x

41. Du Pasquier RA, Kuroda MJ, Zheng Y, Jean-Jacques J, Letvin NL, Koralnik IJ. A prospective study demonstrates an association between JC virusspecific cytotoxic T lymphocytes and the early control of progressive multifocal leukoencephalopathy. Brain (2004) 127(Pt 9):1970-8. doi:10.1093/brain/ awh215

42. Gasnault J, Kahraman M, de Goer de Herve MG, Durali D, Delfraissy JF, Taoufik Y. Critical role of JC virus-specific CD4 T-cell responses in preventing progressive multifocal leukoencephalopathy. AIDS (2003) 17(10):1443-9. doi:10.1097/00002030-200307040-00004

43. Lima MA, Marzocchetti A, Autissier P, Tompkins T, Chen Y, Gordon J, et al. Frequency and phenotype of JC virus-specific $\mathrm{CD}^{+} \mathrm{T}$ lymphocytes in the peripheral blood of patients with progressive multifocal leukoencephalopathy. J Virol (2007) 81(7):3361-8. doi:10.1128/JVI.01621-07

44. Du Pasquier RA, Kuroda MJ, Schmitz JE, Zheng Y, Martin K, Peyerl FW, et al. Low frequency of cytotoxic $T$ lymphocytes against the novel HLA-A ${ }^{*} 0201$ restricted JC virus epitope $\mathrm{VP1}(\mathrm{p} 36)$ in patients with proven or possible progressive multifocal leukoencephalopathy. J Virol (2003) 77(22):11918-26. doi:10.1128/JVI.77.22.11918-11926.2003

45. Du Pasquier RA, Schmitz JE, Jean-Jacques J, Zheng Y, Gordon J, Khalili K, et al. Detection of JC virus-specific cytotoxic T lymphocytes in healthy individuals. J Virol (2004) 78(18):10206-10. doi:10.1128/JVI.78.18.10206-10210.2004

46. Wuthrich C, Kesari S, Kim WK, Williams K, Gelman R, Elmeric D, et al. Characterization of lymphocytic infiltrates in progressive multifocal leukoencephalopathy: co-localization of $\mathrm{CD}^{+} \mathrm{T}$ cells with JCV-infected glial cells. J Neurovirol (2006) 12(2):116-28. doi:10.1080/13550280600716604

47. Achim CL, Wiley CA. Expression of major histocompatibility complex antigens in the brains of patients with progressive multifocal leukoencephalopathy. J Neuropathol Exp Neurol (1992) 51(3):257-63. doi:10.1097/00005072199205000-00003

48. Murali-Krishna K, Altman JD, Suresh M, Sourdive DJ, Zajac AJ, Miller JD, et al. Counting antigen-specific CD8 T cells: a reevaluation of bystander activation during viral infection. Immunity (1998) 8(2):177-87. doi:10.1016/S10747613(00)80470-7

49. Yousef S, Planas R, Chakroun K, Hoffmeister-Ullerich S, Binder TM, Eiermann $\mathrm{TH}$, et al. TCR bias and HLA cross-restriction are strategies of human braininfiltrating JC virus-specific $\mathrm{CD} 4^{+} \mathrm{T}$ cells during viral infection. J Immunol (2012) 189(7):3618-30. doi:10.4049/jimmunol.1201612

50. Jameson SC, Masopust D. Diversity in T cell memory: an embarrassment of riches. Immunity (2009) 31(6):859-71. doi:10.1016/j.immuni.2009.11.007
51. Sallusto F, Lenig D, Forster R, Lipp M, Lanzavecchia A. Two subsets of memory T lymphocytes with distinct homing potentials and effector functions. Nature (1999) 401(6754):708-12. doi:10.1038/44385

52. Masopust D, Schenkel JM. The integration of T cell migration, differentiation and function. Nat Rev Immunol (2013) 13(5):309-20. doi:10.1038/nri3442

53. Skon CN, Lee JY, Anderson KG, Masopust D, Hogquist KA, Jameson SC. Transcriptional downregulation of S1prl is required for the establishment of resident memory CD8 ${ }^{+} \mathrm{T}$ cells. Nat Immunol (2013) 14(12):1285-93. doi:10.1038/ni.2745

54. Matloubian M, Lo CG, Cinamon G, Lesneski MJ, Xu Y, Brinkmann V, et al. Lymphocyte egress from thymus and peripheral lymphoid organs is dependent on S1P receptor 1. Nature (2004) 427(6972):355-60. doi:10.1038/ nature02284

55. Pauls K, Schon M, Kubitza RC, Homey B, Wiesenborn A, Lehmann P, et al. Role of integrin $\alpha_{\mathrm{E}}(\mathrm{CD} 103) \beta_{7}$ for tissue-specific epidermal localization of CD8 ${ }^{+}$ T lymphocytes. J Invest Dermatol (2001) 117(3):569-75. doi:10.1046/j.0022202x.2001.01481.x

56. Casey KA, Fraser KA, Schenkel JM, Moran A, Abt MC, Beura LK, et al. Antigenindependent differentiation and maintenance of effector-like resident memory T cells in tissues. J Immunol (2012) 188(10):4866-75. doi:10.4049/jimmunol. 1200402

57. Graham JB, Da Costa A, Lund JM. Regulatory T cells shape the resident memory $\mathrm{T}$ cell response to virus infection in the tissues. J Immunol (2014) 192(2):683-90. doi:10.4049/jimmunol.1202153

58. Wakim LM, Jones CM, Gebhardt T, Preston CM, Carbone FR. CD8 ${ }^{+}$T-cell attenuation of cutaneous herpes simplex virus infection reduces the average viral copy number of the ensuing latent infection. Immunol Cell Biol (2008) 86(8):666-75. doi:10.1038/icb.2008.47

59. Masopust D. Developing an HIV cytotoxic T-lymphocyte vaccine: issues of CD8 T-cell quantity, quality and location. J Intern Med (2009) 265(1):125-37. doi:10.1111/j.1365-2796.2008.02054.x

60. Masopust D, Choo D, Vezys V, Wherry EJ, Duraiswamy J, Akondy R, et al. Dynamic $\mathrm{T}$ cell migration program provides resident memory within intestinal epithelium. J Exp Med (2010) 207(3):553-64. doi:10.1084/jem.20090858

61. Schenkel JM, Fraser KA, Vezys V, Masopust D. Sensing and alarm function of resident memory CD8 ${ }^{+}$T cells. Nat Immunol (2013) 14(5):509-13 doi:10.1038/ni.2568

62. Gebhardt T, Wakim LM, Eidsmo L, Reading PC, Heath WR, Carbone FR. Memory $\mathrm{T}$ cells in nonlymphoid tissue that provide enhanced local immunity during infection with herpes simplex virus. Nat Immunol (2009) 10(5):524-30. doi:10.1038/ni.1718

63. Masopust D, Picker LJ. Hidden memories: frontline memory $\mathrm{T}$ cells and early pathogen interception. J Immunol (2012) 188(12):5811-7. doi:10.4049/ jimmunol.1102695

64. Wakim LM, Woodward-Davis A, Bevan MJ. Memory T cells persisting within the brain after local infection show functional adaptations to their tissue of residence. Proc Natl Acad Sci US A (2010) 107(42):17872-9. doi:10.1073/pnas. 1010201107

65. Fox RJ, Cohen JA. Multiple sclerosis: the importance of early recognition and treatment. Cleve Clin J Med (2001) 68(2):157-71. doi:10.3949/ccjm.68.2.157

66. Ransohoff RM, Engelhardt B. The anatomical and cellular basis of immune surveillance in the central nervous system. Nat Rev Immunol (2012) 12(9):623-35. doi:10.1038/nri3265

67. Tan CS, Bord E, Broge TA Jr, Glotzbecker B, Mills H, Gheuens S, et al. Increased program cell death-1 expression on T lymphocytes of patients with progressive multifocal leukoencephalopathy. J Acquir Immune Defic Syndr (2012) 60(3):244-8. doi:10.1097/QAI.0b013e31825a313c

68. Keir ME, Butte MJ, Freeman GJ, Sharpe AH. PD-1 and its ligands in tolerance and immunity. Annu Rev Immunol (2008) 26:677-704. doi:10.1146/annurev. immunol.26.021607.090331

69. Wei F, Zhong S, Ma Z, Kong H, Medvec A, Ahmed R, et al. Strength of PD-1 signaling differentially affects T-cell effector functions. Proc Natl Acad Sci USA (2013) 110(27):E2480-9. doi:10.1073/pnas.1305394110

70. Barber DL, Wherry EJ, Masopust D, Zhu B, Allison JP, Sharpe AH, et al. Restoring function in exhausted CD8 T cells during chronic viral infection. Nature (2006) 439(7077):682-7. doi:10.1038/nature04444

71. Schachtele SJ, Hu S, Sheng WS, Mutnal MB, Lokensgard JR. Glial cells suppress postencephalitic CD8 T lymphocytes through PD-L1. Glia (2014) 62:1582-94. doi:10.1002/glia.22701 
72. Parra GI, Bergmann CC, Phares TW, Hinton DR, Atkinson R, Stohlman SA. Gamma interferon signaling in oligodendrocytes is critical for protection from neurotropic coronavirus infection. J Virol (2010) 84(6):3111-5. doi:10.1128/JVI.02373-09

73. Phares TW, Ramakrishna C, Parra GI, Epstein A, Chen L, Atkinson R, et al. Target-dependent B7-H1 regulation contributes to clearance of central nervous system infection and dampens morbidity. J Immunol (2009) 182(9):5430-8. doi:10.4049/jimmunol.0803557

74. Phares TW, Stohlman SA, Hinton DR, Atkinson R, Bergmann CC. Enhanced antiviral $\mathrm{T}$ cell function in the absence of $\mathrm{B} 7-\mathrm{H} 1$ is insufficient to prevent persistence but exacerbates axonal bystander damage during viral encephalomyelitis. J Immunol (2010) 185(9):5607-18. doi:10.4049/jimmunol.1001984

75. Salama AD, Chitnis T, Imitola J, Ansari MJ, Akiba H, Tushima F, et al. Critical role of the programmed death-1 (PD-1) pathway in regulation of experimental autoimmune encephalomyelitis. J Exp Med (2003) 198(1):71-8. doi:10.1084/jem.20022119

76. Zhu B, Guleria I, Khosroshahi A, Chitnis T, Imitola J, Azuma M, et al. Differential role of programmed death-ligand 1 and programmed deathligand 2 in regulating the susceptibility and chronic progression of experimental autoimmune encephalomyelitis. J Immunol (2006) 176(6):3480-9. doi:10.4049/jimmunol.176.9.5683-b

77. Schreiner B, Bailey SL, Shin T, Chen L, Miller SD. PD-1 ligands expressed on myeloid-derived APC in the CNS regulate T-cell responses in EAE. Eur J Immunol (2008) 38(10):2706-17. doi:10.1002/eji.200838137

78. Kroner A, Schwab N, Ip CW, Ortler S, Gobel K, Nave KA, et al. Accelerated course of experimental autoimmune encephalomyelitis in PD-1-deficient central nervous system myelin mutants. Am J Pathol (2009) 174(6):2290-9. doi:10.2353/ajpath.2009.081012

79. Sadagopal S, Lorey SL, Barnett L, Sutherland D, Basham R, Erdem H, et al. Enhanced PD-1 expression by $\mathrm{T}$ cells in cerebrospinal fluid does not reflect functional exhaustion during chronic human immunodeficiency virus type 1 infection. J Virol (2010) 84(1):131-40. doi:10.1128/JVI.01181-09

80. Kinter AL, Godbout EJ, McNally JP, Sereti I, Roby GA, O'Shea MA, et al. The common $\gamma$-chain cytokines IL-2, IL-7, IL-15, and IL-21 induce the expression of programmed death-1 and its ligands. J Immunol (2008) 181(10):6738-46. doi:10.4049/jimmunol.181.10.6738

81. Terawaki S, Chikuma S, Shibayama S, Hayashi T, Yoshida T, Okazaki T, et al. IFN- $\alpha$ directly promotes programmed cell death-1 transcription and limits the duration of T cell-mediated immunity. J Immunol (2011) 186(5):2772-9. doi:10.4049/jimmunol.1003208

82. Gerner MY, Heltemes-Harris LM, Fife BT, Mescher MF. Cutting edge: IL-12 and type I IFN differentially program CD8 T cells for programmed death 1 re-expression levels and tumor control. J Immunol (2013) 191(3):1011-5. doi:10.4049/jimmunol.1300652

83. Jin YH, Hou W, Kang HS, Koh CS, Kim BS. The role of interleukin-6 in the expression of PD-1 and PDL-1 on central nervous system cells following infection with Theiler's murine encephalomyelitis virus. J Virol (2013) 87(21):11538-51. doi:10.1128/JVI.01967-13

84. Nakamichi K, Takayama-Ito M, Nukuzuma S, Kurane I, Saijo M. Longterm infection of adult mice with murine polyomavirus following stereotaxic inoculation into the brain. Microbiol Immunol (2010) 54(8):475-82. doi:10.1111/j.1348-0421.2010.00247.x

85. DeCaprio JA. How the Rb tumor suppressor structure and function was revealed by the study of adenovirus and SV40. Virology (2009) 384(2):274-84. doi:10.1016/j.virol.2008.12.010

86. Bruckner A, Stadlbauer F, Guarino LA, Brunahl A, Schneider C, Rehfuess $\mathrm{C}$, et al. The mouse DNA polymerase alpha-primase subunit p48 mediates species-specific replication of polyomavirus DNA in vitro. Mol Cell Biol (1995) 15(3):1716-24.

87. Tikhanovich I, Nasheuer HP. Host-specific replication of BK virus DNA in mouse cell extracts is independently controlled by DNA polymerase $\alpha$ primase and inhibitory activities. J Virol (2010) 84(13):6636-44. doi:10.1128/ JVI.00527- 10

88. Chia W, Rigby PW. Fate of viral DNA in nonpermissive cells infected with simian virus 40. Proc Natl Acad Sci USA (1981) 78(11):6638-42. doi:10.1073/ pnas.78.11.6638

89. Hacker D, Fluck MM. High-level recombination specific to polyomavirus genomes targeted to the integration-transformation pathway. Mol Cell Biol (1989) 9(3):995-1004.
90. Israel MA, Chan HW, Hourihan SL, Rowe WP, Martin MA. Biological activity of polyoma viral DNA in mice and hamsters. J Virol (1979) 29(3):990-6.

91. London WT, Houff SA, McKeever PE, Wallen WC, Sever JL, Padgett BL, et al. Viral-induced astrocytomas in squirrel monkeys. Prog Clin Biol Res (1983) 105:227-37

92. Major EO, Mourrain P, Cummins C. JC virus-induced owl monkey glioblastoma cells in culture: biological properties associated with the viral early gene product. Virology (1984) 136(2):359-67. doi:10.1016/0042-6822(84) 90172-7

93. Nagashima K, Yasui K, Kimura J, Washizu M, Yamaguchi K, Mori W. Induction of brain tumors by a newly isolated JC virus (Tokyo-1 strain). Am J Pathol (1984) 116(3):455-63.

94. Gordon J, Del Valle L, Otte J, Khalili K. Pituitary neoplasia induced by expression of human neurotropic polyomavirus, JCV, early genome in transgenic mice. Oncogene (2000) 19(42):4840-6. doi:10.1038/sj.onc.1203849

95. Khalili K, Del Valle L, Otte J, Weaver M, Gordon J. Human neurotropic polyomavirus, JCV, and its role in carcinogenesis. Oncogene (2003) 22(33):5181-91. doi:10.1038/sj.onc.1206559

96. Krynska B, Del Valle L, Gordon J, Otte J, Croul S, Khalili K. Identification of a novel p53 mutation in JCV-induced mouse medulloblastoma. Virology (2000) 274(1):65-74. doi:10.1006/viro.2000.0450

97. Trapp BD, Small JA, Pulley M, Khoury G, Scangos GA. Dysmyelination in transgenic mice containing JC virus early region. Ann Neurol (1988) 23(1):38-48. doi:10.1002/ana.410230108

98. Tan CS, Broge TA Jr, Seung E, Vrbanac V, Viscidi R, Gordon J, et al. Detection of JC virus-specific immune responses in a novel humanized mouse model. PLoS One (2013) 8(5):e64313. doi:10.1371/journal.pone.0064313

99. Windrem MS, Schanz SJ, Guo M, Tian GF, Washco V, Stanwood N, et al. Neonatal chimerization with human glial progenitor cells can both remyelinate and rescue the otherwise lethally hypomyelinated shiverer mouse. Cell Stem Cell (2008) 2(6):553-65. doi:10.1016/j.stem.2008.03.020

100. Sim FJ, McClain CR, Schanz SJ, Protack TL, Windrem MS, Goldman SA. CD140a identifies a population of highly myelinogenic, migration-competent and efficiently engrafting human oligodendrocyte progenitor cells. Nat Biotechnol (2011) 29(10):934-41. doi:10.1038/nbt.1972

101. Kondo Y, Windrem MS, Zou L, Chandler-Militello D, Schanz SJ, Auvergne RM, et al. Human glial chimeric mice reveal astrocytic dependence of JC virus infection. J Clin Invest (2014) 124:5323-36. doi:10.1172/JCI76629

102. Van Loy T, Thys K, Ryschkewitsch C, Lagatie O, Monaco MC, Major EO, et al. JC virus quasispecies analysis reveals complex viral population underlying $\mathrm{PML}$ and supports viral dissemination via the hematogenous route. J Virol (2014). doi:10.1128/JVI.02565-14

103. Chapagain ML, Verma S, Mercier F, Yanagihara R, Nerurkar VR. Polyomavirus JC infects human brain microvascular endothelial cells independent of serotonin receptor 2A. Virology (2007) 364(1):55-63. doi:10.1016/j.virol. 2007.02.018

104. Dorries K, Vogel E, Gunther S, Czub S. Infection of human polyomaviruses JC and $\mathrm{BK}$ in peripheral blood leukocytes from immunocompetent individuals. Virology (1994) 198(1):59-70. doi:10.1006/viro.1994.1008

105. Atwood WJ, Amemiya K, Traub R, Harms J, Major EO. Interaction of the human polyomavirus, JCV, with human B-lymphocytes. Virology (1992) 190(2):716-23. doi:10.1016/0042-6822(92)90909-9

106. Lindberg RL, Achtnichts L, Hoffmann F, Kuhle J, Kappos L. Natalizumab alters transcriptional expression profiles of blood cell subpopulations of multiple sclerosis patients. J Neuroimmunol (2008) 194(1-2):153-64. doi:10.1016/ j.jneuroim.2007.11.007

107. Marshall LJ, Ferenczy MW, Daley EL, Jensen PN, Ryschkewitsch CF, Major EO. Lymphocyte gene expression and JC virus noncoding control region sequences are linked with the risk of progressive multifocal leukoencephalopathy. J Virol (2014) 88(9):5177-83. doi:10.1128/JVI.03221-13

108. Houff SA, Berger J, Major EO. Response to Linberg et al. Natalizumab alters transcriptional expression profiles of blood cell subpopulations of multiple sclerosis patients. J Neuroimmunol (2008) 204(1-2):155-6. doi:10.1016/ j.jneuroim.2008.05.007

109. Houff SA, Berger JR. The bone marrow, B cells, and JC virus. J Neurovirol (2008) 14(5):341-3. doi:10.1080/13550280802348222

110. Chapagain ML, Nerurkar VR. Human polyomavirus JC (JCV) infection of human B lymphocytes: a possible mechanism for JCV transmigration across the blood-brain barrier. J Infect Dis (2010) 202(2):184-91. doi:10.1086/653823 
111. Papayannopoulou T, Nakamoto B. Peripheralization of hemopoietic progenitors in primates treated with anti-VLA4 integrin. Proc Natl Acad Sci U S A (1993) 90(20):9374-8. doi:10.1073/pnas.90.20.9374

112. Craddock CF, Nakamoto B, Andrews RG, Priestley GV, Papayannopoulou T. Antibodies to VLA4 integrin mobilize long-term repopulating cells and augment cytokine-induced mobilization in primates and mice. Blood (1997) 90(12):4779-88.

113. Bonig H, Wundes A, Chang KH, Lucas S, Papayannopoulou T. Increased numbers of circulating hematopoietic stem/progenitor cells are chronically maintained in patients treated with the CD49d blocking antibody natalizumab. Blood (2008) 111(7):3439-41. doi:10.1182/blood-2007-09-112052

114. Krumbholz M, Meinl I, Kumpfel T, Hohlfeld R, Meinl E. Natalizumab disproportionately increases circulating pre-B and B cells in multiple sclerosis. Neurology (2008) 71(17):1350-4. doi:10.1212/01.wnl.0000327671.91357.96

115. Zohren F, Toutzaris D, Klarner V, Hartung HP, Kieseier B, Haas R. The monoclonal anti-VLA-4 antibody natalizumab mobilizes $\mathrm{CD} 34^{+}$hematopoietic progenitor cells in humans. Blood (2008) 111(7):3893-5. doi:10.1182/blood2007-10-120329

116. Fluck MM, Schaffhausen BS. Lessons in signaling and tumorigenesis from polyomavirus middle T antigen. Microbiol Mol Biol Rev (2009) 73(3):542-63. doi:10.1128/MMBR.00009-09

117. Rowe WP. The epidemiology of mouse polyoma virus infection. Bacteriol Rev (1961) 25:18-31.

118. Carroll J, Dey D, Kreisman L, Velupillai P, Dahl J, Telford S, et al. Receptorbinding and oncogenic properties of polyoma viruses isolated from feral mice. PLoS Pathog (2007) 3(12):e179. doi:10.1371/journal.ppat.0030179

119. Dawe CJ, Freund R, Mandel G, Ballmer-Hofer K, Talmage DA, Benjamin TL. Variations in polyoma virus genotype in relation to tumor induction in mice. Characterization of wild type strains with widely differing tumor profiles. Am J Pathol (1987) 127(2):243-61.

120. Drake DR III, Moser JM, Hadley A, Altman JD, Maliszewski C, Butz E, et al. Polyomavirus-infected dendritic cells induce antiviral CD8(+) T lymphocytes. J Virol (2000) 74(9):4093-101. doi:10.1128/JVI.74.9.4093-4101.2000

121. Freund R, Garcea RL, Sahli R, Benjamin TL. A single-amino-acid substitution in polyomavirus VP1 correlates with plaque size and hemagglutination behavior. J Virol (1991) 65(1):350-5.

122. Bauer PH, Bronson RT, Fung SC, Freund R, Stehle T, Harrison SC, et al. Genetic and structural analysis of a virulence determinant in polyomavirus VP1. J Virol (1995) 69(12):7925-31.

123. De Mattei M, Martini F, Corallini A, Gerosa M, Scotlandi K, Carinci P, et al. High incidence of BK virus large-T-antigen-coding sequences in normal human tissues and tumors of different histotypes. Int J Cancer (1995) 61(6):756-60 doi:10.1002/ijc.2910610603

124. Drake DR III, Lukacher AE. Beta 2-microglobulin knockout mice are highly susceptible to polyoma virus tumorigenesis. Virology (1998) 252(1):275-84. doi:10.1006/viro.1998.9455

125. Kemball CC, Lee ED, Vezys V, Pearson TC, Larsen CP, Lukacher AE. Late priming and variability of epitope-specific CD8+ T cell responses during a persistent virus infection. J Immunol (2005) 174(12):7950-60. doi:10.4049/jimmunol 174.12.7950
126. Vezys V, Masopust D, Kemball CC, Barber DL, O’Mara LA, Larsen CP, et al. Continuous recruitment of naive $\mathrm{T}$ cells contributes to heterogeneity of antiviral CD8 T cells during persistent infection. J Exp Med (2006) 203(10):2263-9. doi:10.1084/jem.20060995

127. Lukacher AE, Freund R, Carroll JP, Bronson RT, Benjamin TL. Pyvs: a dominantly acting gene in $\mathrm{C} 3 \mathrm{H} / \mathrm{BiDa}$ mice conferring susceptibility to tumor induction by polyoma virus. Virology (1993) 196(1):241-8. doi:10.1006/viro. 1993.1472

128. Beltrami S, Gordon J. Immune surveillance and response to JC virus infection and PML. J Neurovirol (2014) 20(2):137-49. doi:10.1007/s13365-013-0222-6

129. Dalianis T, Hirsch HH. Human polyomaviruses in disease and cancer. Virology (2013) 437(2):63-72. doi:10.1016/j.virol.2012.12.015

130. Han Lee ED, Kemball CC, Wang J, Dong Y, Stapler DC Jr, Hamby KM, et al. A mouse model for polyomavirus-associated nephropathy of kidney transplants. Am J Transplant (2006) 6(5 Pt 1):913-22. doi:10.1111/j.1600-6143. 2006.01265.x

131. Albrecht JA, Dong Y, Wang J, Breeden C, Farris AB III, Lukacher AE, et al. Adaptive immunity rather than viral cytopathology mediates polyomavirusassociated nephropathy in mice. Am J Transplant (2012) 12(6):1419-28. doi:10.1111/j.1600-6143.2012.04005.x

132. McCance DJ. The types of mouse brain cells susceptible to polyoma virus infection in vitro. J Gen Virol (1984) 65(Pt 1):221-6. doi:10.1099/0022-131765-1-221

133. Sebesteny A, Tilly R, Balkwill F, Trevan D. Demyelination and wasting associated with polyomavirus infection in nude (nu/nu) mice. Lab Anim (1980) 14(4):337-45. doi:10.1258/002367780781071021

134. McCance DJ, Sebesteny A, Griffin BE, Balkwill F, Tilly R, Gregson NA. A paralytic disease in nude mice associated with polyoma virus infection. J Gen Virol (1983) 64(Pt 1):57-67. doi:10.1099/0022-1317-64-1-57

135. Harper JS III, Dawe CJ, Trapp BD, McKeever PE, Collins M, Woyciechowska JL, et al. Paralysis in nude mice caused by polyomavirus-induced vertebral tumors. Prog Clin Biol Res (1983) 105:359-67.

Conflict of Interest Statement: The authors declare that the research was conducted in the absence of any commercial or financial relationships that could be construed as a potential conflict of interest.

Received: 23 September 2014; accepted: 03 December 2014; published online: 05 January 2015 .

Citation: Frost EL and Lukacher AE (2015) The importance of mouse models to define immunovirologic determinants of progressive multifocal leukoencephalopathy. Front Immunol. 5:646. doi: 10.3389/fimmu.2014.00646

This article was submitted to Multiple Sclerosis and Neuroimmunology, a section of the journal Frontiers in Immunology.

Copyright (c) 2015 Frost and Lukacher. This is an open-access article distributed under the terms of the Creative Commons Attribution License (CC BY). The use, distribution or reproduction in other forums is permitted, provided the original author(s) or licensor are credited and that the original publication in this journal is cited, in accordance with accepted academic practice. No use, distribution or reproduction is permitted which does not comply with these terms. 